\title{
Statistical modelling for clinical mastitis in the dairy cow: problems and solutions
}

\author{
Patrick GASQUI*, Jacques BARNOUIN \\ Unité d'Épidémiologie Animale, INRA, 63122 Saint-Genès-Champanelle, France
}

(Received 9 October 2002, accepted 16 June 2003)

\begin{abstract}
Modelling case occurrence and risk factors for clinical mastitis, as a key multifactorial disease in the dairy cow, requires statistical models. The type of model used depends on the choice of perception or the study level: herd, lactation, animal, udder and quarter. The validity of the tests that are performed through these models is especially ensured when hypotheses of independence between statistical units are respected, and when the model adjustments do not involve overdispersion faced with the observed data. In the article, the main sources of overdispersion are identified according to the different levels of perception of mastitis risk. Then, the proposed solutions to control for overdispersion at each study level are discussed and the difficulty to compare the study results is highlighted through a variety of methodological choices of the authors. Two main categories of models are used for modelling clinical mastitis, i.e. generalist exploratory models and explanatory designed models. The contribution of the explanatory models to improve modelling accuracy and relevance is documented through the two main published methodological approaches, the first one being based on a states model, and the second on a survival model. The integration and optimisation of such explanatory modelling methods should be possible in the future in order to develop a more global explanatory model including herd risk factors, which could pertinently predict udder infections (both clinical and subclinical) at the cow, lactation, or even udder and quarter levels.
\end{abstract}

clinical mastitis / dairy cow / epidemiology / modelling / overdispersion

Table of contents

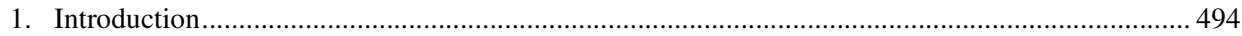

2. Statistical modelling for clinical mastitis: problems and solutions ................................................. 494

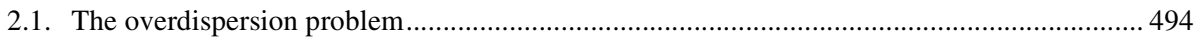

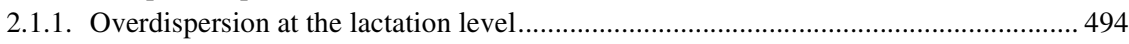

2.1.2. Overdispersion at the animal level........................................................................ 495

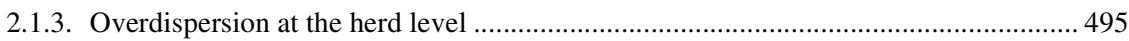

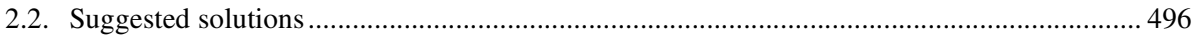

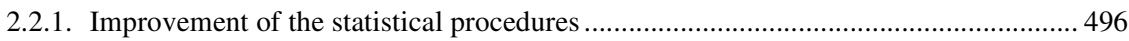

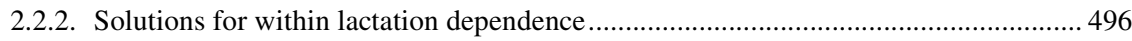

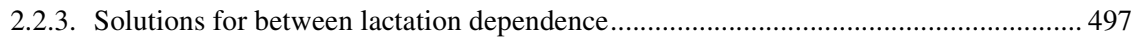

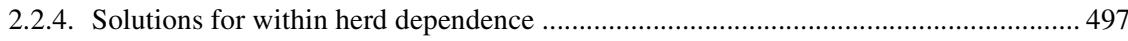

\footnotetext{
* Corresponding author: Patrick.Gasqui@clermont.inra.fr
} 


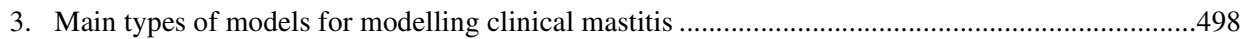

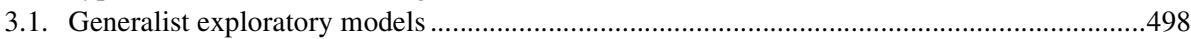

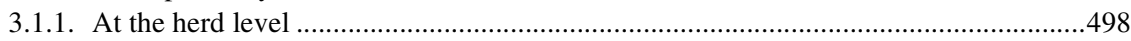

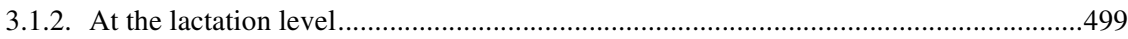

3.1.3. Contribution of the generalist exploratory models ......................................................49

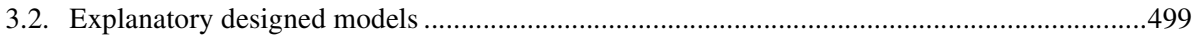

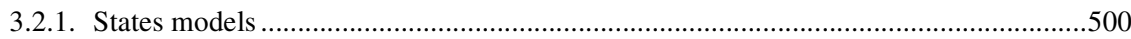

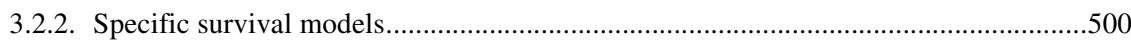

3.2.3. Contribution of the explanatory designed models ......................................................50

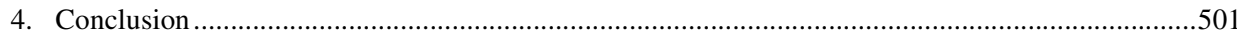

\section{INTRODUCTION}

Clinical mastitis in the dairy cow (CMAST) is the archetype of a multifactorial disease $[8,31]$. Udder inflammationsinfections are determined through numerous factors (breeding practices, including housing hygiene and the quality of milking, feeding characteristics, weather conditions, genetic parameters) as well as aetiological determinants (major, minor and facultative pathogens, macro and micro traumas) $[4,6$, 28, 81]. Moreover, since such factors can be implicated in different study levels (herd, cow, teat) which are not independent, CMAST is at the same time a predilection field for modelling and a restricting methodological framework.

All statistical models used by the epidemiologist to study CMAST risk factors or predict CMAST occurrence require suitability between the hypotheses for statistical modelling and the samples analysed. Whatever analysis method used to identify risk factors, the hypothesis of independence between the observed events is especially necessary and remains a major restricting problem concerning this field of study. CMAST modelling involves different levels of dependence, which are potential sources for the overdispersion of the observed data at the different study levels: between different herds of the same region, within the same herd surveyed over a long time period, between different animals within the same herd, between successive lactations/cases for the same animal, or between udder quarters (Fig. 1). Moreover, important potential sources for overdispersion are factors which are not taken into account or, worse, are unidentifiable. Identifying and taking into account an overdispersion in the analysis process is essential for the validity of the statistical results, the estimation of the parameters and the level of significance of the statistical tests [21, 61].

Faced with such difficulties, the authors tried to take these different constraints into consideration. The aim of the present article was to review and discuss the main methodological issues in CMAST modelling (except through specific genetic models) and the solutions which are proposed by the epidemiologists.

\section{STATISTICAL MODELLING FOR CLINICAL MASTITIS: PROBLEMS AND SOLUTIONS}

\subsection{The overdispersion problem}

\subsubsection{Overdispersion at the lactation level}

In the dairy cow, the number of CMAST cases during a lactation (and herd CMAST incidence rate) can be modelled according to the Poisson distribution because of its random nature $[36,50]$. Concerning the herd incidence rate, a binomial distribution must be performed for a dichotomous variable (lactation with/without CMAST). Unfortunately, these theoretical distributions are rarely observed because of the 


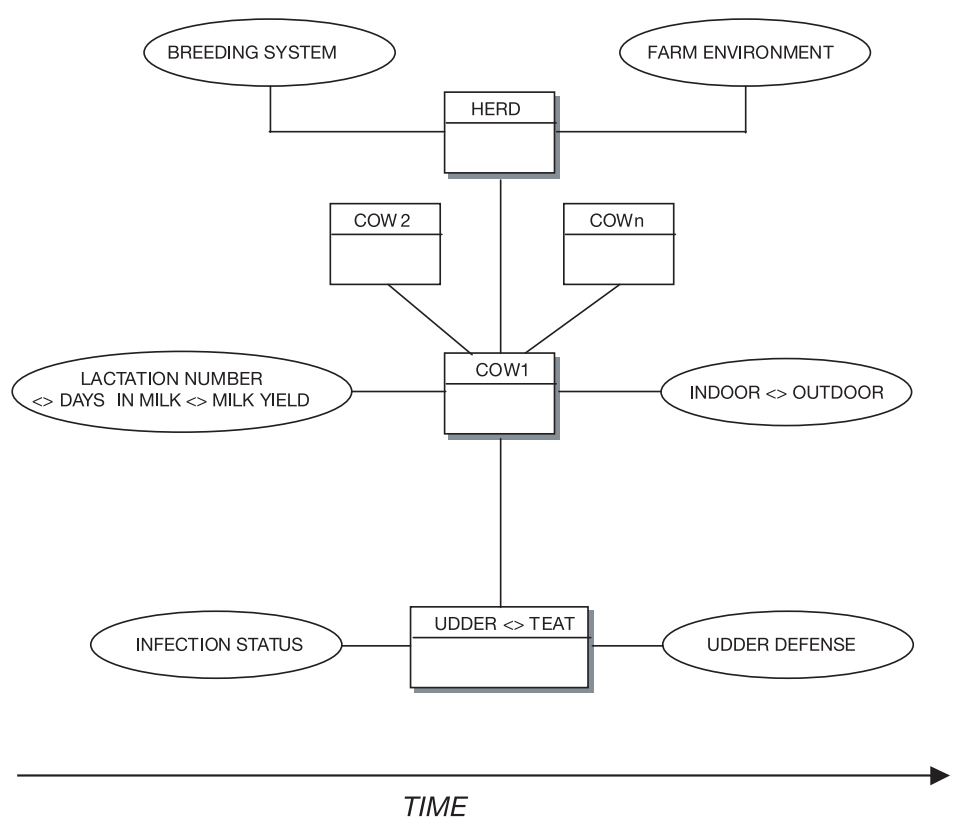

Figure 1. An overview of mastitis study levels and factors.

presence of overdispersion of the studied data [50, 63], which involves defective adjustments and incorrect statistical tests.

\subsubsection{Overdispersion at the animal level}

Successive CMAST reoccurrences cannot be systematically considered as independent, depending on udder pathogen persistence [36]. Nevertheless other characteristics of the observed lactations may also generate overdispersion. This is the case when important factors of variation are not taken into account depending on herd managerial conditions (housing and grazing periods including different levels of risk for CMAST occurrence) [37] or when the true course of the lactation is not considered [36]. Finally, the CMAST observed distribution at the lactation level would involve some overdispersion compared to the expected theoretical distribution.

At the animal level, it is not possible to consider that consecutive lactations includ- ing the CMAST cases are independent. CMAST occurrence in a selected lactation depends on udder infection status at the previous lactation for multiparous females or at the prepartum period for the primiparous [37]. As at the animal level, the basic characteristics of lactation (duration, parity, yield level) are also important to consider in the modelling process. Even if the lactation events are summarised in a dichotomous way (CMAST vs. CMASTfree), overdispersion can be observed when the data are adjusted for a binomial theoretical distribution [21].

\subsubsection{Overdispersion at the herd level}

At the herd level, when the herd is considered as a whole, or when time disease evolution for consecutive years is studied, CMAST cases are not really independent. A herd is characterised by its specific environmental conditions, by germs remaining in the environment or in the udder. Such a 
heterogeneity could also increase overdispersion, whatever is the index summarising the herd disease information.

\subsection{Suggested solutions}

\subsubsection{Improvement of the statistical procedures}

In epidemiology, the study level of predilection is the population. In CMAST epidemiological studies, the population both corresponds to a set of herds, animals, lactations and udder quarters. In order to take into account such a complexity concerning CMAST risk levels, several modelling strategies were performed in the literature $[26,27,64,75]$. The degree of complexity of the multivariate models which are used to predict the risk is the consequence of the different study levels which are interwoven in CMAST epidemiology. Such a complexity is better integrated with statistical packages. For example, the writers of SAS software (SAS Software System, SAS Institute Inc., Cary, NC, USA) finalised the CATMOD procedure (categorical data analysis), the LOGISTIC procedure (linear regression models for binary response as well as ordinary response data), GENMOD procedure (which fits the generalised linear models and allows the response probability to be any number of an exponential family) and finally the MIXED procedure (including random effect models and a variety of mixed linear models to fit data). These improvements allow to rule out losses of information concerning the samples which are induced by the statistical selection in order to ensure the mutual independence and absence of correlation between the data. These method evolutions permit to estimate different levels of dependence or correlation between some statistical units. Moreover, the introduction of random effects in the model allows to take into consideration some sources of overdispersion, in an empirical method.

\subsubsection{Solutions for within lactation dependence}

To improve the independence between animals and consecutive clinical cases, constraints were imposed by the authors in the sample selection process. Nevertheless, it is obvious that such a practice induces a systematic loss of information to the detriment of the accuracy and finally the ability of the statistical procedure to highlight the potential risk factors.

The widely adopted solution consists in removing within the lactation new CMAST cases occurring in a pre-established time interval after the primary case. Since no precise biological justification allows the choice of a well-defined censure duration, there is a significant variability in the chosen durations (lag time for a new case) according to different authors. Lag time for a new CMAST case varies from 0 to 90 days, including the value 0 [76], 7 [60], 8 [55], $10[16,17,56], 14[3,11,28,73]$, $15[13,34], 30[24,30,51,59,67,68]$ or 90 days [57]. Some authors highlight this lag time variability while varying this parameter from 4 to 28 days [79] or from 0 to 30 days [50] starting from the same initial data. Finally, these authors used a value of 9 days, close to the value of the 8 days recommended by the International Dairy Federation (IDF) [50]. The comparison between different studies is all the more difficult since some authors do not specify the value used in their analyses [9, 10, 45, 47, 69]. Moreover, the knowledge or not of udder bacteriological status [38], including various levels of accuracy, still complicates the between-study comparisons. Some authors have tried to define synthetic indices allowing the study of CMAST reoccurrences without censoring [65]. In other studies, more explanatory models integrating biological concepts have been developed to take into account the notion of non independence in a simulation model $[1,2]$ or in a statistical model $[36,37]$. All the authors who model CMAST using this procedure used a model based on a Poisson 
distribution (Poisson regression or Poisson model through Generalised Linear Models (GLM)) [61].

In some studies data are more significantly censored, since the first CMAST occurrence within the lactation is only considered. Within these studies, a binary type response is sometimes chosen: CMAST free lactations vs. lactations with at least one CMAST case $[11,14,16,17,32,39$ $41,55,72,77-79,81,83]$. Such a choice is recommended [55] and carried out for genetic studies $[23,42,43,52,53,60,67$, $70,80]$. According to the same approach, the expression of this dichotomous response is sometimes limited to a subperiod of the lactation: from 7 days before calving to 7 days after calving [66], the 5 first days after calving [19], the first 14 days [73, 82], the first 30 days [7, 20,74], the first 60 days [6], the first 100 days [18], or even a calendar year instead of the lactation [79]. The International dairy Federation recommends considering the 30 days before calving for primiparous animals [50]. In other studies, lactation is divided into different successive periods: according to the 4 seasons [60], 2 periods of 2 and 7 months [15], or 4 periods [29]. The periods are even fixed by some authors in a cumulative way [ 43 , 44].

Fixing the duration of the observational period enables easier between-study comparisons than taking into account the whole lactation, whatever the duration of the lactation. Among the lactation splitters, some keep only one occurrence within the lactation $[15,29]$, or integrate the minimal time interval between consecutive CMAST cases (see above). These authors aim to obtain over one specific period, and not on the whole lactation, a dichotomous response. The analysis models are mainly based on a binomial distribution (logistic regression, or binomial model through the Generalised Linear Models (GLM)) [21, 61]. Other authors consider the date of occurrence of the first CMAST case within the lactation, choosing the calving date as the initial moment [71]. This is the main analysis framework of survival models, especially the Cox models [33].

\subsubsection{Solutions for between lactation dependence}

To study a potential dependence between lactations, some authors consider only one lactation per animal. The first lactation, especially in genetic studies, is often selected $[42-44,53,60,66,70,81,82]$, or the two first lactations when the study is aimed at evaluating the influence of the first lactation on the second lactation $[67,71,72$, 77]. In other cases, one lactation is randomly selected among the available lactations for a given animal, which allows to consider the lactation number as the explanatory variable $[17,19,20,51,80]$.

\subsubsection{Solutions for within herd dependence}

It is also necessary to consider the question of herd dependence in the course of time and of animal dependence for animals living within the same herd. As previously presented, when a set of herds is surveyed, the main source of overdispersion (except the problem of following the same herd all along a time period) is a lack of consideration of significant (and generally unknown) factors of heterogeneity in the model. To overcome the overdispersion problem, the models try to estimate it using a theoretic distribution of Poisson, or a theoretic distribution yet including an overdispersion through a negative binomial or a beta-binomial distribution [75]. When the same herds are studied in a prospective survey, the models allow to estimate a within herd variance through an extension of GLM procedures (Generalised Estimated Equations or GEE) [25]. Moreover a herd fixed or random effect is usually entered in the models, besides the fixed effects corresponding to other control, key or explanatory variables. In large scale surveys, a random herd effect 
is generally entered to save the degrees of freedom, to the detriment of an accurate estimation of the residual variance, which is important in order to precisely test the factors of interest. When few and not randomly selected herds are defined and used in the model, the introduction of a fixed effect herd factor is better. Moreover between-study comparisons are difficult because the control variables of the final model are very often different according to the study. When the analysed response at the herd level is increasingly built from more or less censored responses to subjacent levels (animal, lactation and case), the optimal consideration of the problem is harder.

The herd level study mainly depends on the definition of the index, qualifying the response variable (incidence, incidence rate), and characterising a herd at a given moment or in a time period. A significant part of the between herd observed heterogeneity depends on the index calculation and the characterisation of the CMAST case in a herd [50]. In most studies, significant efforts have been made to homogenise mastitis definition criteria (at least the observation of lumps in milk), standardise their clinical description, and confirm the infection through milk quarter bacteriology. Another problem is to normalise the calculation of a synthetic CMAST incidence rate, since at least 12 different definitions of CMAST incidence rate are given by the authors [50]. In the literature, CMAST indices are calculated as percentages of infected lactations by the total number of lactations or lactations at risk, or occurrences (more or less censored) observed for different periods and calculated as the numbers of days, weeks or months at risk. According to the calculation, either the observed lactation duration is not considered or the time interval while an animal is not at risk after a CMAST occurrence is a priori variably chosen. In other respects, the calculation from the overall number of lactations (or specific lactation periods) with at least one
CMAST is then related to the numbers of cows-lactation at risk $[6,11,17,32,39,41$, $52,55,79]$ or of CMAST-free months [14, 15]. When the calculation is made from the total number of cases (per udder or per quarter), it is divided by the total number of cows-day at risk $[3-5,11,30,34,48,54$, $55,69,79]$, the study period within the lactation [13], or even by the number of cowsweek $[9,10,56]$ or cows-month $[28,48$, 54]. Sometimes, the calculation procedure is not mentioned [45, 47]. It is important to indicate that the calculation of the number of CMAST cases including a number of days at risk mainly depends on [79] the a priori chosen value (from 0 to 90 days according to the study), which allows to decide if a new case occurs.

\section{MAIN TYPES OF MODELS FOR MODELLING CLINICAL MASTITIS}

\subsection{Generalist exploratory models}

Two main modelling approaches are performed to identify the CMAST risk factors: the first is based on a binomial distribution, essentially at the lactation level, and the second on a Poisson distribution, used at lactation and herd levels. It is obvious that going from the herd to the lactation level, the sample selection is more difficult and crucial, in relation with methodological problems.

\subsubsection{At the herd level}

At the herd level, it seems important to consider a potential overdispersion, at least in an empiric way, even if the causes of overdispersion are not identified. An analysis based on the Poisson model (through a GLM procedure) is then adapted while including a random herd effect $[13,19,41$, 52]. Another choice is the use of a negative binomial distribution instead of the Poisson distribution [4, 69, 75]. The elementary 
estimation of the overdispersion in a Poisson regression $[4,5,28]$ does not allow an accurate control of the significance of the tests concerning the factor effects. An analysis of variance, carried out from the ranks of the herds classified according to CMAST incidence (Kruskal-Wallis test) [34], is less precise in terms of risk factor identification, since independence hypotheses are still necessary for its use.

\subsubsection{At the lactation level}

At the lactation level, a dichotomous response based on a binomial distribution allows the exclusion of a potential dependence between successive CMAST cases within a lactation. If a single lactation is selected for each animal, a multiple logistic regression model can be performed through the GML procedure, including at least one herd or animal effect [24, 29, 70], or through a survival model when considering the time occurrence of the first CMAST of the lactation [71]. If several lactations of the same animal are selected, a random animal or lactation effect must be considered. An alternative method is the use of a GEE model including the estimation of within lactation correlations for one animal, or between animal correlations within a herd [41]. Modelling based on a beta-binomial distribution can also be performed. This takes a potential overdispersion into account [75]. This is also possible through a case-control survey, by pairing a CMAST case with a within herd control, to use a single lactation per animal and define a dichotomous response for the lactation in order to minimise the different dependence problems [82]. But when using these methods, the numbers of analysed statistical units are sharply decreased and consequently it is not reasonable to accurately evaluate the studied factors.

When the number of lactations including CMAST cases is considered in the model, the overdispersion problem is more difficult to overcome, since all the overdispersion sources are potentially present for all
CMAST perception levels, and the choice of a censoring period between successive cases is determinant. Thus, when using generalist models, it can be recommended to limit the number of the studied perception levels, by selecting for example the lactations which are studied for each animal. Such a solution was chosen in a study of successive recurrences in the lactation period through a logistic model (in a GEE model), which is aimed at estimating the correlation matrix between successive events within a lactation [78]. Earlier methodological issues have tried to solve the problem defining indices which allow to study successive reoccurrences $[17,65]$. An empiric approach has also been developed, through a negative binomial distribution including a 30-d censoring period [59]. It nevertheless seems difficult to go on using statistical analysis generalist methods like random effect models with the aim to study all potential overdispersion sources.

\subsubsection{Contribution of the generalist exploratory models}

Finally, it appears very difficult to compare in a relevant way the different studies using generalist exploratory models, and to carry out meta-analyses. From the analysis of the available studies, it seems to be unlikely to more accurately identify CMAST risk factors through these generalised methods. Moreover, some highlighted risk factors using generalist approaches are not relevant, since they do not completely and accurately remove the different various levels of dependence and efficiently control the first kind error ( $\alpha$-error). An alternative to the use of the generalist models is to develop explanatory designed models based on a more integrative and causal approach.

\subsection{Explanatory designed models}

With the generalist exploratory models, the problem is to adapt the data to an existing statistical model available in a statistical software. The authors exclude sample 
data information (lactation selection, lagtime of cases, etc.) to respect the hypothesis of the statistical model used. The aim is to identify risk factors in an analysis approach. From another point of view, it is possible to construct a biological model based on a lot of knowledge developed in particular with exploratory model results. This biological model has then translated in a statistical model which in general, is not directly available in a statistical software. The specific model obtained (with biological and statistical parts) is an explanatory model. It is possible to use all sample data information in this synthesis approach.

\subsubsection{States models}

The knowledge of CMAST epidemiology allows to try to develop more explanatory models based on biological parameters, as previously recommended [62]. Consequently, a nearly accurate approach was developed via a simulator based on the definition of states (uninfected, subclinically infected, clinically infected or recovered susceptibles) and probabilities of state changes (Fig. 2) through three methodological issues: Markov processes, discreteevent simulation and differential equations $[1,2]$. While such an approach allows to study a germ effect at the quarter or udder level, it does not allow to test potential risk factor effects, except through many simulation results.

\subsubsection{Specific survival models}

Another method is based on distribution mixtures in survival models. This is developed with the aim of a CMAST statistical model by modelling the dependence between successive events within the lactation, and from one lactation to another (Fig. 3). Such a method easily integrates observable biological parameters $[36,37]$. This approach, performed at the udder level, integrates the animal and lactation levels and allows to test individual and/or herd risk factors. Through this work, it is possible to study the distribution of CMAST cases per lactation and the distribution of CMAST occurrence periods. Nevertheless, the method does not integrate at the present time the variability due to mastitis risk factors at the herd level.

\subsubsection{Contribution of the explanatory designed models}

The two proposed explanatory designed models are synthesis paths for CMAST modelling from the results of the generalist exploratory models. These two modelling ways (exploratory or empirical vs. explanatory) are complementary $[22,58]$.

These new synthetic approaches could help to solve previously notified problems, such as the confounding factors and the integration of various levels of dependence. With such models, housing and grazing periods, and more generally all timedependent variables [1,37], can be considered at the animal level. The study of such variables associated with that of an infection rate effect at calving allows to rule out the lactation stage factor as one of the main

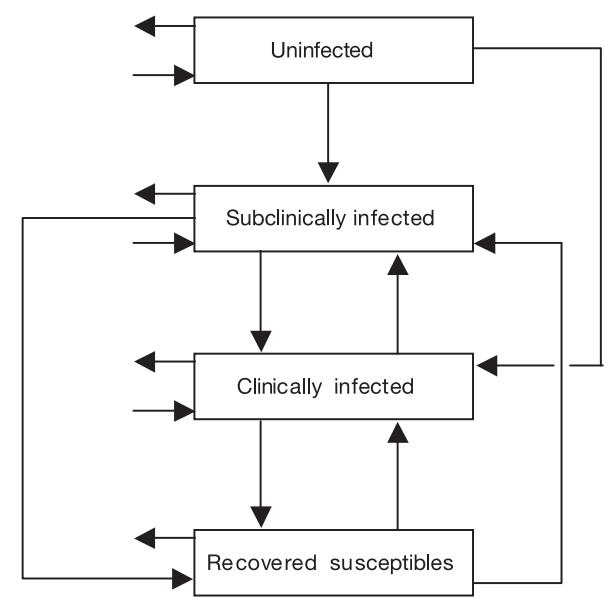

Figure 2. Diagram showing the modelling elements making it possible to take into account dynamically different udder-health states in the same animal (adapted from [1]). 


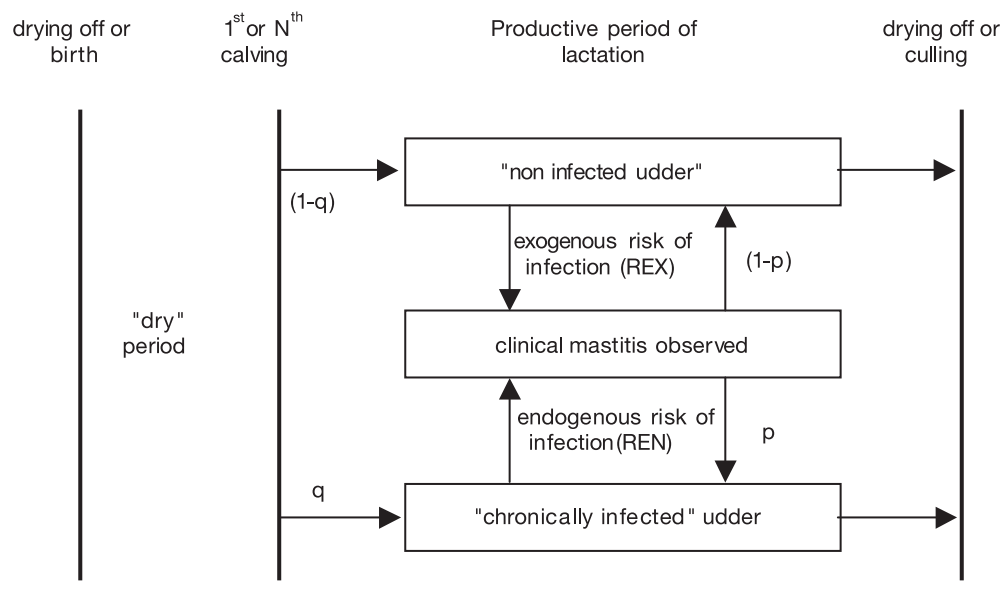

Figure 3. Diagram showing the modelling elements making it possible to take into account a relationship between consecutive cases of mastitis within lactation and between consecutive lactations in the same animal (reproduced from [37] with permission).

structural variables for mastitis risk from the modelling process [37]. Consequently, such explanatory designed models intend to decrease the confounding problems. With such models, the dependence between successive cases within a lactation can explicitly be considered by these models [36]. In the future, the modelling could be significantly improved by performing the study at the quarter level since quarter bacteriological status could be determined. Through this design, it would be possible to combine the two explanatory models already published $[1,2,36,37]$. Such explanatory models could also help to define optimum criteria for incidence rate definition at the herd level, even to justify the time lag in order to eliminate successive reoccurrences within a lactation. The model developed from the survival functions $[36,37]$ only considers the first CMAST occurrence in a lactation, or builds the analysis on a dichotomous response at the lactation level (in the absence of recurrence parameters, more than one clinical mastitis case per lactation in the epidemiological context of the experimental studied herds could not occur).

But explanatory modelling techniques require more scientific investment than the generalist exploratory models. Nevertheless, they allow to add to the modelling, as published through a dynamic discrete event stochastic simulation model $[1,2]$, the main epidemiological and experimental knowledge concerning the CMAST risk.

\section{CONCLUSION}

Considering the variety of the available modelling techniques in epidemiology [49], it is detrimental that only a few CMAST specific explanatory modelling approaches have been published. The development of such approaches could involve a significant improvement in the field of bovine mastitis research, the disease remaining an economic and hygienic problem for all dairy channels $[12,35,46]$. The next step would be to integrate udder inflammation markers into the CMAST explanatory model, essentially milk somatic cell counts (SCC), in order to model in a synthetic attempt both clinical and subclinical mastitis after reviewing and discussing the previously published SCC modelling and simulation techniques. 


\section{ACKNOWLEDGEMENTS}

We sincerely thank Natacha Blaszczyk (Unité d'Épidémiologie Animale, INRA) for the translation of this article.

\section{REFERENCES}

[1] Allore H.G., Erb H.N., Approaches to modeling intramammary infections in dairy cattle, Prev. Vet. Med. 39 (1999) 279-293.

[2] Allore H.G., Schruben L.W., Erb H.N., Oltenacu P.A., Design and Validation of a Dynamic Discrete Event Stochastic Simulation Model of Mastitis Control in Dairy Herds, J. Dairy Sci. 81 (1998) 703-717.

[3] Barkema H.W., Schukken Y.H., Lam T.J.G.M., Beiboer M.L., Wilmink H., Benedictus G., Brand A., Incidence of Clinical Mastitis in Dairy Herds Grouped in Three Categories by Bulk Milk Somatic Cell Counts, J. Dairy Sci. 81 (1998) 411-419.

[4] Barkema H.W., Schukken Y.H., Lam T.J.G.M., Beiboer M.L., Benedictus G., Brand A., Management Practices Associated with the Incidence Rate of Clinical Mastitis, J. Dairy Sci. 82 (1999) 1643-1654

[5] Barkema H.W., Van Der Ploeg J.D., Schukken Y.H., Lam T.J.G.M., Benedictus G., Brand A., Management Style and Its Association with Bulk Milk Somatic Cell Count and Incidence Rate of Clinical Mastitis, J. Dairy Sci. 82 (1999) 1655-1663.

[6] Barnouin J., Chassagne M., Factors associated with clinical mastitis incidence in French dairy herds during late gestation and early lactation, Vet. Res. 29 (1998) 159-171.

[7] Barnouin J., Chassagne M., Predictive variables for the occurrence of early clinical mastitis in primiparous Holstein cows under field conditions in France, Can. Vet. J. 42 (2001) 47-53.

[8] Barnouin J., Fayet J.C., Jay M., Brochart M., Enquête éco-pathologique continue : facteurs de risque des mammites de la vache laitière. I. Analyses multidimensionnelles sur données d'élevage, Can. Vet. J. 27 (1986) 135145 .

[9] Bartlett P.C., Miller G.Y., Lance S.E., Heider L.E., Clinical mastitis and intramammary infections on Ohio dairy farms, Prev. Vet. Med. 12 (1992) 59-71.

[10] Bartlett P.C., Miller G.Y., Lance S.E., Heider L.E., Environmental and managerial determinants of somatic cell counts and clinical mas- titis incidence in Ohio dairy herds, Prev. Vet. Med. 14 (1992) 195-207.

[11] Bartlett P.C., Agger J.F., Houe H., Lawson L.G., Incidence of clinical mastitis in Danish dairy cattle and screening for non-reporting in a passively collected national surveillance system, Prev. Vet. Med. 48 (2001) 78-83.

[12] Beaudeau F., Seegers H., Ducrocq V., Fourichon C., Bareille N., Effect of health disorders on culling in dairy cows: a review and a critical discussion, Ann. Zootech. 49 (2000) 293-311.

[13] Beaudeau F., Fourichon C., Seegers H., Bareille N., Risk of clinical mastitis in dairy herds with a high proportion of low individual milk somatic-cell counts, Prev. Vet. Med. 53 (2002) 43-54.

[14] Bendixen P.H., Vilson B., Ekesbo I., Astrand D.B., Disease frequencies of tied zero-grazing dairy cows and of dairy cows on pasture during summer and tied during winter, Prev. Vet. Med. 4 (1986) 291-306.

[15] Bendixen P.H., Vilson B., Ekesbo I., Astrand D.B., Disease Frequencies in Dairy Cows in Sweden. V. Mastitis, Prev. Vet. Med. 5 (1988) 263-274.

[16] Bigras-Poulin M., Meek A.H., Martin S.W., Interrelationships among Health Problems and Milk Production from Consecutive Lactations in Selected Ontarion Holstein Cows, Prev. Vet. Med. 8 (1990) 15-24.

[17] Bigras-Poulin M., Meek A.H., Martin S.W., McMillan I., Health problems in selected Ontario Holstein cows: frequency of occurrences, time to first diagnosis and associations, Prev. Vet. Med. 10 (1990) 79-89.

[18] Bradley A.J., Green M.J., An Investigation of the Impact of Intramammary Antibiotic Dry Cow Therapy on Clinical Coliform Mastitis, J. Dairy Sci. 84 (2001) 1632-1639.

[19] Calavas D., Faye B., Bugnard F., Ducrot C., Raymond F., Analysis of associations among diseases in French dairy cows in two consecutive lactations, Prev. Vet. Med. 27 (1996) 43-55.

[20] Chassagne M., Barnouin J., Chacornac J.P., Biological predictors for early clinical mastitis occurrence in Holstein cows under field conditions in France, Prev. Vet. Med. 35 (1998) 29-38.

[21] Collett D., Modelling Binary Data, Chapman \& Hall, London, 1991.

[22] Cox D.R., Role of Models in Statistical Analysis, Statistical Sci. 5 (1990) 169-174. 
[23] De Haas Y., Barkema H.W., Veerkamp R.F., Genetic parameters of pathogen-specific incidence of clinical mastitis in dairy cows, Anim. Sci. 74 (2002) 233-242.

[24] Detilleux J.C., Kehrli M.E., Freeman A.E., Fox L.K., Kelley D.H., Mastitis of Periparturient Holstein Cattle: A Phenotypic and Genetic Study, J. Dairy Sci. 78 (1995) 22852293.

[25] Diggle P.J., Liang K., Zeger S.L., Analysis of longitudinal Data, Clarendon Press, Oxford, 1994.

[26] Donald A., Prevalence estimation using diagnostic tests when there are multiple, correlated diseases states in the same animal or farm, Prev. Vet. Med. 15 (1993) 125-145.

[27] Donald A.W., Estimating the prevalence of mastitis and other organ-specific diseases in the presence of within-animal disease correlation and diagnostic test correlation, Prev. Vet. Med. 20 (1994) 113-133.

[28] Elbers A.R.W., Miltenburg J.D., De Lange D., Crauwels A.P.P., Barkema H.W., Schukken Y.H., Risk Factors for Clinical Mastitis in a Random Sample of Dairy Herds from the Southern Part of The Netherlands, J. Dairy Sci. 81 (1998) 420-426.

[29] Emanuelson U., Oltenacu P.A., Incidences and Effects of Diseases on the Performance of Swedish Dairy Herds Stratified by Production, J. Dairy Sci. 81 (1998) 2376-2382.

[30] Fang W., Jiang C., Liu H., Epidemiologic aspects of bovine mastitis and its control in several dairy herds in southeastern China, Prev. Vet. Med. 15 (1993) 169-180.

[31] Faye B., Waltner-Toews D., McDermott J., From 'ecopathology' to 'agroecosystem health', Prev. Vet. Med. 39 (1999) 111-128.

[32] Fleischer P., Metzner M., Beyerbach M., Hoedemaker M., Klee W., The Relationship Between Milk Yield and the Incidence of Some Diseases in Dairy Cows, J. Dairy Sci. 84 (2001) 2025-2035.

[33] Fleming T.R., Harrington D.P., Counting Processes and Survival Analysis, John Wiley \& Sons, New York, 1991.

[34] Fourichon C., Beaudeau F., Bareille N., Seegers H., Incidence of health disorders in dairy farming systems in western France, Livest. Prod. Sci. 68 (2001) 157-170.

[35] Fourichon C., Seegers H., Beaudeau F., Verfaille L., Bareille N., Health-control costs in dairy farming systems in western France, Livest. Prod. Sci. 68 (2001) 141-156.
[36] Gasqui P., Pons O., Coulon J.B., An individual modelling tool for consecutive clinical mastitis during the same lactation in dairy cows: a method based on a survival model, Vet. Res. 31 (2000) 583-602.

[37] Gasqui P., Coulon J.B., Pons O., An individual modelling tool for within and between lactation consecutive cases of clinical mastitis in the dairy cow: an approach based on a survival model, Vet. Res. 34 (2003) 85-104.

[38] Gonzalez R.N., Jasper D.E., Kronlund N.C., Farver T.B., Cullor J.S., Bushnell R.B., Dellinger J.D., Clinical Mastitis in Two California Dairy Herds Participating in Contagious Mastitis Control Programs, J. Dairy Sci. 73 (1990) 648-660.

[39] Gröhn Y.T., Erb H.N., McCulloch C.E., Saloniemi H.S., Epidemiology of Mammary Gland Disorders in Multiparous Finnish Ayrshire Cows, Prev. Vet. Med. 8 (1990) 241252 .

[40] Gröhn Y.T., Eicker S.W., Hertl J.A., The Association Between Previous 305-day Milk Yield and Disease in New York State Dairy Cows, J. Dairy Sci. 78 (1995) 1693-1702.

[41] Hardeng F., Edge V.L., Mastitis, Ketosis, and Milk Fever in 31 Organic and 93 Conventional Norwegian Dairy Herds, J. Dairy Sci. 84 (2001) 2637-2679.

[42] Heringstad B., Klemetsdal G., Ruane J., Clinical Mastitis in Norwegian Cattle: Frequency, Variance Components, and Genetic Correlation with Protein Yield, J. Dairy Sci. 82 (1999) 1325-1330.

[43] Heringstad B., Klemetsdal G., Ruane J., Variance components of clinical mastitis in dairy cattle effects of trait definition and culling, Livest. Prod. Sci. 67 (2001) 265-272.

[44] Heringstad B., Rekaya R., Gianola D. Klemetsdal G., Weigel K.A., Bayesian Analysis of Liability of Clinical Mastitis in Norwegian Cattle with a Threshold Model: Effects of Data Sampling Method and Model Specification, J. Dairy Sci. 84 (2001) 2337 2346.

[45] Hillerton J.E., Bramley A.J., Staker R.T., McKinnon C.H., Patterns of intramammary infection and clinical mastitis over a 5 year period in a closely monitored herd applying mastitis control measures, J. Dairy Res. 62 (1995) 39-50.

[46] Hortet P., Seegers H., Loss in milk yield and related composition changes resulting from clinical mastitis in dairy cows, Prev. Vet. Med. 37 (1998) 1-20. 
[47] Hu S., Fang W., Lu H., Jiang C., Zhu P., Ye J., Ye D., Yan H., Effect of teat dipping and dry cow therapy on mastitis in a commercial dairy herd in China, Prev. Vet. Med. 10 (1990) 91-96.

[48] Hurd H.S., Kaneene J.B., The National Animal Health Monitoring System in Michigan. II. Methodological Issues in the Estimation of Frequencies of Disease in a Prospective Study of Multiple Dynamic Populations, Prev. Vet. Med. 8 (1990) 115-125.

[49] Hurd H.S., Kaneene J.B., The application of simulation models and systems analysis in epidemiology: a review, Prev. Vet. Med. 15 (1993) 81-99.

[50] International Dairy Federation, Recommendations for representation of mastitis-related data, Bulletin of the IDF, IDF, Bruxelles, 321 (1997) 16-21.

[51] Judge L.J., Erskine R.J., Bartlett P.C., Recombinant Bovine Somatotropin and Clinical Mastitis: Incidence, Discarded Milk Following Therapy, and Culling, J. Dairy Sci. 80 (1997) 3212-3218.

[52] Kadarmideen H.N., Pryce J.E., Genetic and economic relationship between somatic cell count and clinical mastitis and their use in selection for mastitis resistance in dairy cattle, Anim. Sci. 73 (2001) 19-28.

[53] Kadarmideen H.N., Rekaya R., Gianola D., Genetic parameters for clinical mastitis in Holstein-Friesians in the United Kingdom: a Bayesian analysis, Anim. Sci. 73 (2001) 229240.

[54] Kaneene J.B., Hurd H.S., The National Animal Health Monitoring System in Michigan. I. Design, Data and Frequencies of Selected Dairy Cattle Diseases, Prev. Vet. Med. 8 (1990) 103-114.

[55] Kelton D.F., Lissemore K.D., Martin R.E., Recommendations for Recording and Calculating the Incidence of Selected Clinical Diseases of Dairy Cattle, J. Dairy Sci. 81 (1998) 2502-2509.

[56] Lafi S.Q., Al-Rawashdeh O.F., Ereifej K.I., Hailat N.Q., Incidence of clinical mastitis and prevalence of subclinical udder infections in Jordanian dairy cattle, Prev. Vet. Med. 18 (1994) 89-98.

[57] Lancelot R., Faye B., Lescourret F., Factors affecting the distribution of clinical mastitis udder quarters in French dairy cows, Vet. Res. 25 (1997) 45-53.

[58] Lehmann E.L., Model Specification: The Views of Fisher and Neyman, and Later
Developments, Statistical Sci. 5 (1990) 160168.

[59] Lescourret F., Coulon J.B., Faye B., Predictive Model of Mastitis Occurrence in the Dairy Cow, J. Dairy Sci. 78 (1995) 21672177.

[60] Lund M.S., Jensen J., Petersen P.H., Estimation of Genetic and Phenotypic Parameters for Clinical Mastitis, Somatic Cell Production Deviance, and Protein Yield in Dairy Cattle Using Gibbs Sampling, J. Dairy Sci. 82 (1999) 1045-1051.

[61] McCullagh P., Nelder J.A., Generalized Linear Models, 2nd ed., Chapman \& Hall, London, 1989.

[62] McDermott J.J., Progress in analytic methods - more sophistication or back to basics? Prev. Vet. Med. 25 (1995) 121-133.

[63] McDermott J.J., Schukken Y.H., A review of methods used for cluster effects in explanatory epidemiological studies of animal populations, Prev. Vet. Med. 18 (1994) 155-173.

[64] McDermott J.J., Schukken Y.H., Shoukri M.M., Study design and analytic methods for data collected from clusters of animals, Prev. Vet. Med. 18 (1994) 175-191.

[65] Morse D., DeLorenzo M.A., Wilcox C.J., Natzke R.P., Bray D.R., Occurrence and Reoccurrence of Clinical Mastitis, J. Dairy Sci. 70 (1987) 2168-2175.

[66] Myllis V., Rautala H., Characterization of Clinical Mastitis in Primiparous Heifers, J. Dairy Sci. 78 (1995) 538-545.

[67] Nash D.L., Rogers G.W., Cooper J.B., Hargrove G.L., Keown J.F., Hansen L.B., Heritability of Clinical Mastitis Incidence and Relationships with Sire Transmitting Abilities for Somatic Cell Score, Udder Type Traits, Productive Life, and Protein Yield, J. Dairy Sci. 83 (2000) 2350-2360.

[68] Oltenacu P.A., Natzke R.P., Mathematical Modeling of Mastitis Infection Process, J. Dairy Sci. 59 (1975) 515-521.

[69] Peeler E.J., Green M.J., Fitzpatrick J.L., Morgan K.L., Green L.E., Risk Factors Associated with Clinical Mastitis in Low Somatic Cell Count British Dairy Herds, J. Dairy Sci. 83 (2000) 2464-2472.

[70] Rupp R., Boichard D., Genetic Parameters for Clinical Mastitis, Somatic Cell Score, Production, Udder Type Traits, and Milking Ease in First Lactation Holsteins, J. Dairy Sci. 82 (1999) 2198-2204

[71] Rupp R., Boichard D., Relationship of early first lactation somatic cell count with risk of 
subsequent first clinical mastitis, Livest. Prod. Sci. 62 (2000) 169-180.

[72] Rupp R., Beaudeau F., Boichard D., Relationship between milk somatic-cell counts in the first lactation and clinical mastitis occurrence in the second lactation of French Holstein cows, Prev. Vet. Med. 46 (2000) 99111.

[73] Schnier C., Hielm S., Saloniemi H.S., Comparison of the disease incidences of dairy cows kept in cold and warm loose-housing systems, Prev. Vet. Med. 53 (2002) 247-261.

[74] Schukken Y.H., Erb H.N., Smith R.D., The Relationship between Mastitis and Retained Placenta in a Commercial Population of Holstein Dairy Cows, Prev. Vet. Med. 5 (1988) 181-190.

[75] Schukken Y.H., Casella G., van den Brock J., Overdispersion in clinical mastitis data from dairy herds: a negative binomial approach, Prev. Vet. Med. 10 (1991) 239-245.

[76] Shpigel N.Y., Winkler M., Ziv G., Saran A., Clinical, bacteriological and epidemiological aspects of clinical mastitis in Israeli dairy herds, Prev. Vet. Med. 35 (1998) 1-9.

[77] Slettbakk T., Jorstad A., Farver T.B., Holmes J.C., Impact of milking characteristics and morphology of udder and teats on clinical mastitis in first- and second-lactation Norwe- gian cattle, Prev. Vet. Med. 24 (1995) 235 244.

[78] Suriyasathaporn W., Schukken Y.H., Nielen M., Brand A., Low Somatic Cell Count: a Risk Factor for Subsequent Clinical Mastitis in a Dairy Herd, J. Dairy Sci. 83 (2000) $1248-1255$

[79] Sviland S., Waage S., Clinical bovine mastitis in Norway, Prev. Vet. Med. 54 (2002) 65-78.

[80] Uribe H.A., Kennedy B.W., Martin S.W. Kelton D.F., Genetic Parameters for Common Health Disorders of Holstein Cows, J. Dairy Sci. 78 (1995) 421-430.

[81] Waage S., Sviland S., Odegaard S.A., Identification of Risk Factors for Clinical Mastitis in Dairy Heifers, J. Dairy Sci. 81 (1998) 1275-1284.

[82] Waage S., Odegaard A., Lund A., Brattgjerd S., Rothe T., Case-Control Study of Risk Factors for Clinical Mastitis in Postpartum Dairy Heifers, J. Dairy Sci. 84 (2001) 392-399.

[83] Washburn S.P., White S.L., Green J.T., Benson G.A., Reproduction, Mastitis, and Body Condition of Seasonally Calved Holstein and Jersey Cows in Confinement or Pasture Systems, J. Dairy Sci. 85 (2002) 105111. 